\title{
Multi-scale influence of vapor pressure deficit on fire ignition and spread in boreal forest ecosystems
}

\author{
F. Sedano ${ }^{1,2}$ and J. T. Randerson ${ }^{3}$ \\ ${ }^{1}$ Department of Geographical Sciences, University of Maryland, College Park, Maryland, USA \\ ${ }^{2}$ Earth Science Division, Code 610, NASA/Goddard Space Flight Center, Greenbelt, Maryland 20771, USA \\ ${ }^{3}$ Department of Earth System Science, University of California, Irvine, California, USA \\ Correspondence to: F. Sedano (fsedano@umd.edu)
}

Received: 2 December 2013 - Published in Biogeosciences Discuss.: 22 January 2014

Revised: 1 May 2014 - Accepted: 26 May 2014 - Published: 18 July 2014

\begin{abstract}
Climate-driven changes in the fire regime within boreal forest ecosystems are likely to have important effects on carbon cycling and species composition. In the context of improving fire management options and developing more realistic scenarios of future change, it is important to understand how meteorology regulates different aspects of fire dynamics, including ignition, daily fire spread, and cumulative annual burned area. Here we combined ModerateResolution Imaging Spectroradiometer (MODIS) active fires (MCD14ML), MODIS imagery (MOD13A1) and ancillary historic fire perimeter information to produce a data set of daily fire spread maps for Alaska during 2002-2011. This approach provided a spatial and temporally continuous representation of fire progression and a precise identification of ignition and extinction locations and dates for each wildfire. The fire-spread maps were analyzed with daily vapor pressure deficit (VPD) observations from the North American Regional Reanalysis (NARR) and lightning strikes from the Alaska Lightning Detection Network (ALDN). We found a significant relationship between daily VPD and likelihood that a lightning strike would develop into a fire ignition. In the first week after ignition, above average VPD increased the probability that fires would grow to large or very large sizes. Strong relationships also were identified between VPD and burned area at several levels of temporal and spatial aggregation. As a consequence of regional coherence in meteorology, ignition, daily fire spread, and fire extinction events were often synchronized across different fires in interior Alaska. At a regional scale, the sum of positive VPD anomalies during the fire season was positively correlated with annual burned area during the NARR era $\left(1979-2011 ; R^{2}=\right.$
\end{abstract}

0.45). Some of the largest fires we mapped had slow initial growth, indicating opportunities may exist for suppression efforts to adaptively manage these forests for climate change. The results of our spatiotemporal analysis provide new information about temporal and spatial dynamics of wildfires and have implications for modeling the terrestrial carbon cycle.

\section{Introduction}

Fire plays an important role in regulating carbon and energy fluxes in boreal forest ecosystems on multiple time scales. Carbon emissions during combustion vary considerably as a function of fire weather, topography, permafrost status, and past fire history (Harden et al., 2000; Amiro et al, 2001; Balshi et al., 2007; de Groot et al., 2009; Kasischke and Hoy, 2012). Over a period of decades, fire is one of several types of disturbance that influence the distribution of forest stand ages and thus is an important factor regulating the magnitude of terrestrial carbon fluxes across regions (Harden et al., 2000; Bond-Lamberty et al., 2007; Balshi et al., 2009; McGuire et al., 2009). On longer time scales, fires influence the carbon cycle through their impacts on permafrost active layer depths (Jorgerson et al., 2010; O'Donell et al., 2011; Nossov et al., 2013), thermokarst dynamics (Myers-Smith et al., 2008), and the stability of deep soil organic carbon layers (Harden et al., 2006). In parallel, fires influence surface energy fluxes by means of several interrelated pathways. By killing overstory trees and initiating succession, fires modify vegetation composition over a period of decades (Johnstone and Kasischke 2005; Goetz et al., 2007; Verbyla, 2008; 
Johnstone et al., 2010) that, in turn, influences surface albedo (Randerson et al. 2006; Lyons et al., 2006) and sensible and latent heat fluxes (Liu et al., 2005; Amiro et al., 2006; Lee et $\mathrm{al}, 2011)$. These fire-ecosystem interactions have the potential to modify regional climate (Rogers et al., 2013) and influence boreal forest species composition (Goetz et al., 2007; Johnstone et al., 2011; Barrett et al., 2011; Mann et al., 2012; Hollingsworth et al., 2013).

Major uncertainties remain in understanding how boreal fire regimes are likely to respond to climate warming. Burned area in boreal North America has increased over the last several decades (Gillet et al., 2004; Kasischke and Turetsky 2006). Changes in fire disturbance regimes have already occurred (Turetsky et al., 2011; Beck and Goetz, 2011) and future climate change scenarios point towards additional changes (Flannigan et al., 2005; Amiro et al., 2009; Balshi et al., 2009; de Groot et al., 2013). Variations in fire frequency, intensity, size, and spatial and seasonal distributions may increase fire severity and carbon emissions (Kasischke et al., 2010, Turetsky et al., 2011) and affect post-fire vegetation regeneration and succession (Chapin, et al., 2004; Goetz, et al., 2007; Johnstone, et al., 2011; Hollingsworth, et al., 2013). In this context, more information about climate influence on different aspects of fire dynamics, including ignition, spread, and extinction, is needed to develop more realistic models of future change.

Several studies have explored the relationship between large-scale atmospheric processes and wildfire activity in boreal ecosystems. Skinner et al. (1999) studied circulation anomalies in the mid-troposphere and identified statistically significant correlations between regional annual burned area in Canada and $5000 \mathrm{hPa}$ geopotential heights. Hess et al. (2001) reported linkages between El Niño events, weather patterns in Alaska, and annual burned area in Alaska. Duffy et al. (2005) quantified the impact of variations in atmospheric circulation and weather variables on fire season severity in Alaska, concluding that the average June temperature could explain one-third of the variability in the logarithm of annual burned area. Subsequent studies have combined meteorological variables and fire weather indices with step-wise regression (Flannigan et al., 2005) and multivariate adaptive regression splines (Balshi et al., 2009b) to estimate burned area at large spatial scales under future climate warming scenarios.

While these studies provide insight about some of the climate factors influencing large fire years in boreal ecosystems at regional level, there is still a lack of information about meteorological controls on different aspects of fire dynamics at finer scales. This information is needed to develop more mechanistic models describing the ignition and evolution of fires under scenarios of future climate warming derived from Earth system model simulations. Recently Abatzoglou and Kolden (2011) worked to close this gap by increasing the spatial and temporal resolution of their climate-fire analysis. The authors found that while antecedent weather conditions

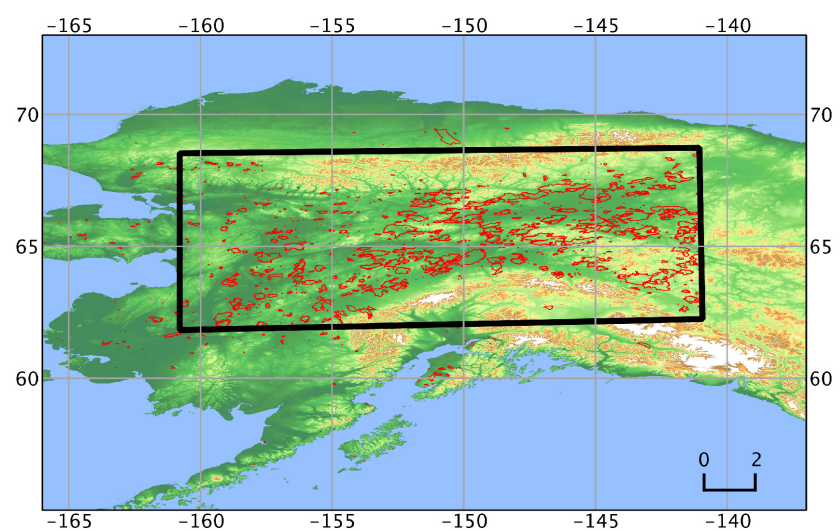

Figure 1. Location of the study area in interior Alaska $\left(62^{\circ} \mathrm{N}-\right.$ $69^{\circ} \mathrm{N}, 161^{\circ} \mathrm{W}-141^{\circ} \mathrm{W}$ ) superimposed on an elevation map and 2002-2011 fire perimeters from the Alaska Large Fire Database (LFDB).

have negligible importance on fire growth, post-ignition conditions and the timing of precipitation events are critical determinants of fire size in boreal forests.

Building on this work, we developed daily maps of fire progression with a $1 \mathrm{~km}$ resolution for approximately 700 wildfires in interior Alaska during 2002-2011 using MODIS active fire observations and fire perimeters from the Alaska Fire Service. To our knowledge this represents the largest data set of daily wildland fire spread in boreal ecosystems. We then used these fire-spread maps with North American Regional Reanalysis data (Mesinger et al., 2006) to investigate how climate influences lightning-driven ignition, and separately, how climate influences fire spread and burned area on synoptic, seasonal, and interannual time scales. Our analyses identified consistent relationships between vapor pressure deficit and daily burned area for individual fires, between vapor pressure deficit and daily regional burned area, and between mean summer vapor pressure deficit and annual burned area. These results provide new information about the temporal and spatial dynamics of wildfires in boreal forest ecosystems and have implications for modeling the terrestrial carbon cycle and the design mitigation strategies.

\section{Data and area of study}

\subsection{Study area}

The area of study covered an extent of circa $725000 \mathrm{~km}^{2}$ in the Alaskan Intermontane Boreal Interior (Nowacki et al., 2001) (Fig. 1). Spanning regions from longitudes $141^{\circ}-$ $159^{\circ} \mathrm{W}$ and latitudes $62^{\circ}-69^{\circ} \mathrm{N}$ this area included the land between the Canadian border to the east, the Innoko area to the west, the south slope of the Brooks Range to the north and the north slope of the Alaska Range to the south. The 
vast majority of historical wildland fires in Alaska occurred within this study domain.

\subsection{Data products}

We used active fire information from the MODIS Active Fire Global Monthly Fire Location Product (MCD14ML) (Giglio, 2010) to develop our maps of daily fire spread. The MCD14ML product consists of an ASCII list of all of the fire thermal anomalies locations, and detected a resolution of approximately $1 \mathrm{~km}$ at the time of overpass of the Terra or Aqua satellites. The fire detection algorithm combines contextual information, a spectral threshold in the middle-infrared, and thermal-infrared brightness temperatures to identify fires and separate them from bright clouds and other variations in the background imagery (Giglio et al., 2003). The MCD14ML product includes geographic coordinates for each active fire detection, as well as information about the time and date, satellite, scan angle, brightness temperatures, detection confidence and fire radiative power. For this study, we used active fires with detection confidence levels higher than $50 \%$ from both the Aqua and Terra satellites. This set accounted for $22.7 \%$ of all the active fires within the study domain during 2002-2011.

To refine fire perimeter identification and identify unburned islands within the fire perimeters we created difference-normalized burn ratio (dNBR) spectral index images using Collection 5 of the MODIS Vegetation Indices product (MOD13A1). MOD13A1 provides near infrared and medium infrared 16-day composites at $500 \mathrm{~m}$ spatial resolution with a sinusoidal projection. For each fire the images from the second June composite in the year preceding and following the burn were acquired for the dNBR calculation. Three tiles (h10v02, h11v02 and h12v02) were required to cover to study area. The images were reprojected into a geographic projection (WGS84) using the MODIS Reprojection Tool (https://lpdaac.usgs.gov/tools/modis_reprojection tool). The Alaska Large Fire Database (LFDB) for the State of Alaska (Kasischke et al., 2002) was used to identify the final perimeters of large wildland fires for our fire spread analysis. LFDB covers the period from 1940-2012 and includes information on a variety of attributes, including fire name, start date, close out date, estimated size, and cause.

We obtained meteorological data from the North American Regional Reanalysis (NARR) archived at the National Climatic Data Center (NCDC) (Kalnay et al., 1996; Mesinger et al., 2006). NARR combines observations and a climate model in a data assimilation system to provide sub-daily information ( 3 hourly) for 45 meteorological variables at a $32 \mathrm{~km}$ spatial resolution from 1979 to 2012 . From this data set we extracted information on relative humidity and air temperature at $2 \mathrm{~m}$ heights above surface for the midday interval (15:00-18:00 p.m. Alaska time). The NARR daily raster images also were projected to the WGS84 geographic projection.
To verify that daily air temperatures $\left({ }^{\circ} \mathrm{C}\right)$ from NARR were able to reproduce observed variations at weather stations, we conducted the following analysis during the 2004 fire season. First, we extracted daily maximum air temperature records from the NOAA National Climatic Data Center for twelve stations within the area of study in interior Alaska from Day of Year (DOY) 150-270. The twelve weather stations were Manley Hot Springs, Ben Creek, Big Delta Airport, Angel Creek, Chalkyitsik, Bettles Airport, Gold King, Chatanika, Cottonwood, Beaver WBQ, Circle Hot Springs, and Farewell. Daily air temperatures from weather stations were calculated as the average of the daily maximum temperatures for the twelve ground stations. Daily air temperatures for NARR were calculated as the average of all pixels within the area of study (spatial resolution $32 \mathrm{~km}$, image size of $46 \times 44$ pixels). For this comparison, NARR captured much of the variability in the observations (with a correlation coefficient of 0.95) and reproduced many of the sharp transitions associated with synoptic fronts moving through the region. A similar analysis with VPD yielded a lower correlation coefficient of 0.71 , likely as a consequence of representativeness errors in the observations and higher uncertainties in model simulations of water vapor. Lightning data was obtained from the Alaska Lightning Detection Network (ALDN) maintained by the Bureau of Land Management Alaska Fire Service (AFS) (Reap, 1991). In the year 2000, the lightning detection network included 11 integrated IMPACT sensors. This system records strikes hitting the ground, with lightning strikes occurring in close proximity in time and space recorded as single strikes (Alaska Interagency Coordination Center, personal communication).

Previous studies have documented spatial accuracies for lightning detections processed after 1995 on the order of 2 $4 \mathrm{~km}$. Detection efficiencies are assumed to be between 60 $80 \%$ in interior Alaska (Dissing and Verbyla, 2003). Under ideal conditions, the detection sensors provide a detection efficiency of $99 \%$ and a median location accuracy of $500 \mathrm{~m}$ or better (Vaisala Oyj, 2011). The ALDN provides a vector spatial representation of lightning strikes for each year during 1986-2012. Additionally it also contains attribute fields on location (latitude and longitude) and date (time, day and year), polarity and number of recorded strokes. For this study we extracted data for the period 2002-2011.

\section{Methods}

\subsection{Fire spread estimation method}

We interpolated MCD14ML active fires detection times within LFDB perimeters to retrieve a spatially continuous (raster) representation of the time at which each pixel burned. The output is a raster layer resampled at 500-meter spatial resolution of the date of burning for each year during 2002 2011 (Fig. 2). Satellite sensors with high revisit frequencies 
A
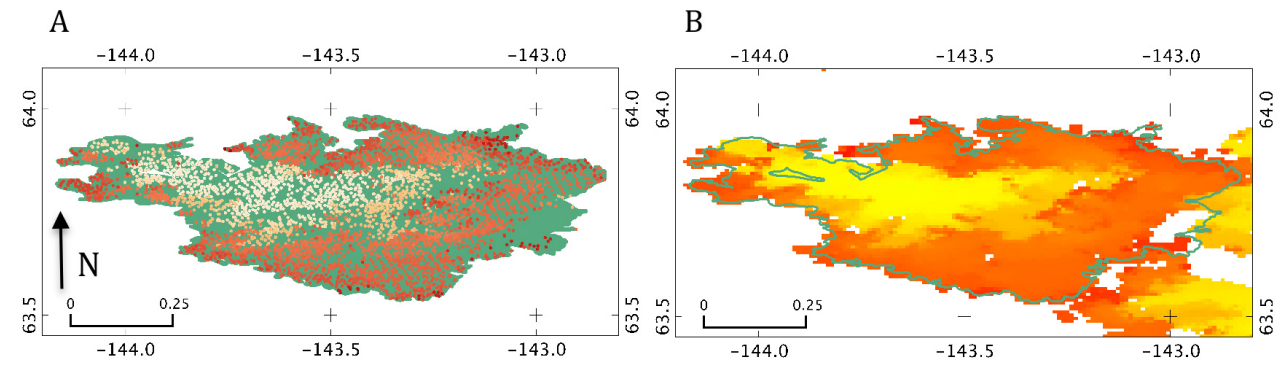

C

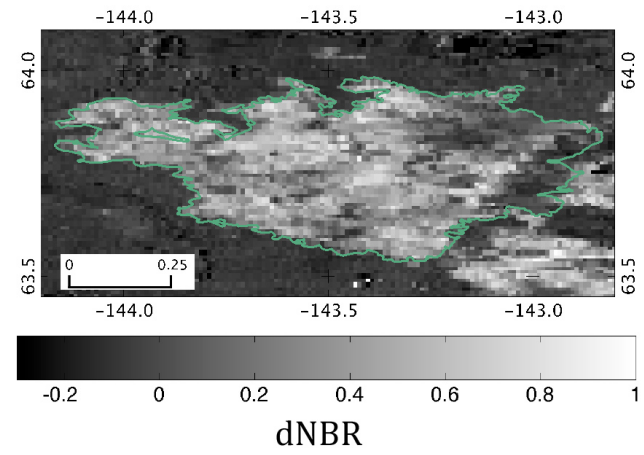

$\mathrm{D}$

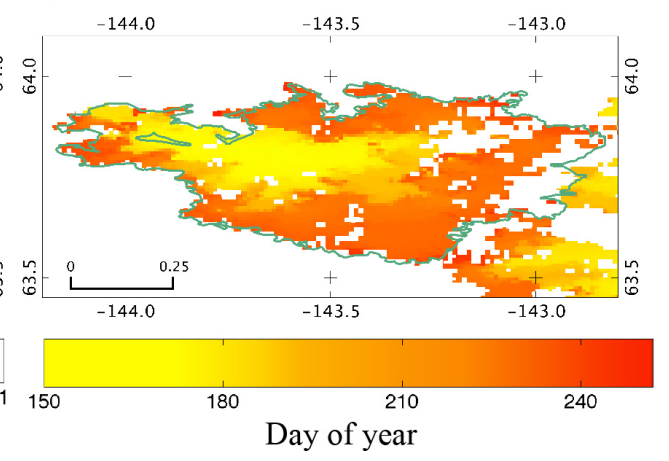

Figure 2. Active fires and daily fire spread for the Billy Creek fire that burned during the summer of 2004. (A) Active fires within the LFDB perimeter; (B) the fire spread map after spatial interpolation; (C) the difference-normalized burn ratio index (dNBR) estimated from $500 \mathrm{~m}$ MODIS data from June 2003 (pre-fire) and June 2005 (post-fire; (D) fire spread map after applying dNBR-based mask to remove unburned islands.

have proven useful for obtaining information on wildfire occurrence and progression (Boschetti et al., 2010). Previous studies have used active fire information from MODIS to obtain information about fire spread. Loboda and Csiszar (2007), for example, estimated fire spread rates for wildfires in northern Eurasia solely based on active fire information. More recently Thorsteinsson et al. (2011) used MODIS active fires to monitor the evolution of a single fire event in Iceland and Kasischke and Hoy (2012) combined active fires and fire perimeters in an attempt to estimate daily carbon emissions for a set of 41 fires in Alaska.

To retrieve a consistent and reliable fire spread map the number of active fires for a single wildfire must be sufficiently large and their distribution within the perimeter must be relatively homogeneous. While this can be a limitation at lower latitudes, the shorter MODIS revisit period at higher latitudes provides dense active fire distributions within the perimeter of many large fires. Still, the spatiotemporal pattern of active fires can be discontinuous because of factors such as cloud and smoke coverage, and variable fire spread. The spatial interpolation approach must be robust to minimize the influence of discontinuous active fires spatial patterns and produce reliable results under a wide variety of conditions. We chose an inverse distance weight interpolation (IDW) for the spatial interpolation of active fire detection dates. IDW is an exact deterministic interpolation approach that calculates values at unknown locations as a weighted av- erage of the values at known locations within a fixed spatial context (Watson and Philip 1985). The weights are assigned following an inverse relationship to the spatial distances between unknown and known locations. Although relatively simple, IDW is a flexible approach that requires a limited number of initial parameters and enables a straightforward physical interpretation. By establishing a minimum number of known locations to be included in the analysis, IDW limits its sensitivity to outliers and ensures the robustness of the interpolation. This interpolation method has been extensively used to retrieve continuous representations of a variety of environmental variables such as precipitation, temperature, or elevation from point data (Chen and Liu, 2012; Didari et al., 2012; Schwendel et al., 2012). While more sophisticated statistical interpolation methods, such as kriging, exist, their more severe assumptions cannot be always met and their increasing complexity commonly requires a larger number of empirical parameters.

The IDW spatial interpolation consists of two steps. The first calculates the weights for each unknown location based on its distance to known locations (Eq. 1). The second combines the weights and the values at the known locations to 
solve for the value at the unknown location (Eq. 2):

$$
\begin{aligned}
& w_{i}(x)=\frac{1}{d\left(x, x_{i}\right)^{p}} \\
& u(x)=\sum_{i=0}^{N} \frac{w_{i}(x) u\left(x_{i}\right)}{\sum_{i}^{N} w_{i}(x)},
\end{aligned}
$$

where $x$ is the unknown location; $x_{i}$ are known locations; $w_{i}$ are the pair weights; $d$ are the distances between two locations; $p$ is the power parameter; $N$ is the number of closest known locations used for the calculation; and $u$ is the calculated value at an unknown location.

The interpolation output is sensitive to the initial parameter selection. While small search radii can result in gaps in the final product, very large search areas result in excessively smooth surfaces. Larger $p$ values assign higher weights to neighboring locations. After a preliminary analysis of active fire spatial patterns and the potential parameter combinations for the study area, we selected a circular neighborhood radius of $1 \mathrm{~km}$, a power of 2 , and a minimum of 3 and maximum of 10 active fires for the number of known locations. Because of the absence of active fires within the defined search radius, for some small and short-lived fires, the IDW interpolation was not always able to assign a progression date to each pixel within the fire perimeters. Nonetheless, this combination of parameters retained the spatial structure of active-fire burning dates while minimizing the number of gaps in the final map.

The day of the year was selected as interpolation variable. Sub-daily estimates at unknown locations were truncated to the day. If less than three active fires existed within the $1 \mathrm{~km}$ circular radius neighborhood, the fire progression was not calculated for that pixel. The annual fire spread maps also provided estimates of fire ignition and extinction dates and locations. Ignition and extinction dates were defined for each fire as the date of the first and last active fire detected within a fire perimeter respectively. However the precise detection of the ignition and extinction dates can be affected by time lags with the time of overpass of satellites and the absence of cloud free imagery. Aqua MODIS detections became available in July of 2002, and as a consequence, the active fires used in the IDW interpolation for the first months of the time series originated solely from Terra. Although the spatial density of active fires during this interval was lower, the IDW interpolation yielded successful retrievals of fire spread rates that likely had higher levels of uncertainty (e.g., Veraverveke et al., 2014).

The IDW interpolation of active fires can potentially retrieve values for unburned islands within the fire perimeters, resulting in an overestimation of the burned area for individual fires and aggregated burned area statistics at regional level. To remove these unburned pixels a mask based on the difference-normalized burned ratio (dNBR) index was applied. The dNBR is a spectral index that compares pre and post fire values of the normalized burned ratio index (NBR) taking advantage of the differences in spectral signatures before and after fire to identify burned areas and burned area severity. The dNBR has been extensively tested as a proxy for fire severity. While some studies have documented positive relationships between spectral indices and fire severity (Epting et al., 2005; Loboda et al., 2007; De Santis and Chuvieco 2007; Verbyla et al., 2008), others have argued against their utility (Hoy et al., 2008; Murphy et al., 2008). In this study the dNBR index was solely used to estimate burned areas. The spectral index was calculated from $500 \mathrm{~m}$ spatial resolution MODIS imagery (MOD13A1), using antecedent and posterior images to the year of each fire. Pre and postfire 16-day composites for the calculation of the dNBR were always selected from the same composite, between June and July (DOY 177 to 192). This narrow sampling interval for the MOD13A composites reduced Bidirectional reflectance distribution function (BRDF) effects that can be potentially large at high latitudes. The corresponding MODIS band 2 $(841-876 \mathrm{~nm})$ and band $7(2105-2155 \mathrm{~nm})$ were used as near-infrared (NIR) and short wave-infrared (SWIR) bands for the calculation. A dNBR-based mask was created by applying a threshold between burned and unburned surface, with dNBR values smaller than 0.15 considered as unburned pixels. Subsequently the dNBR mask was used to remove unburned pixels from the fire-spread maps.

$\mathrm{NBR}=\frac{(\mathrm{NIR}-\mathrm{SWIR})}{(\mathrm{NIR}+\mathrm{SWIR})}$
$\mathrm{dNBR}=$ NBRpre - NBRpost

Finally fire perimeters were overlaid on the annual fire spread maps in order to assign the fire patches generated in the interpolation to fires recorded in the LFDB data set. The LFDB included a total of 966 fires for the study area in the period 2002-2011. Of the 966 fires in the database, 289 fire perimeters, with an average size of $74 \mathrm{ha}$, did not have any active fire within their perimeter. These fires represented $0.35 \%$ of the burned area during 2002-2011. Because of the lack of active fires the information on fire progression for these fires could not be generated. One hundred and seventy fire patches generated from the spatial interpolation of the active fires did not correspond to any fire perimeter in the LFDB. The average size of these patches was 200 ha and they accounted for $0.57 \%$ of the burned area during 2002-2011. Since these fires could not be associated with any event in the LFDB they also were not considered in the analysis. Given the limited size of fires without active fires and the small amount of burned area corresponding to fires not registered in the LFDB, their exclusion is unlikely to affect the outcome of the analyses described below.

Daily burned area was computed as the number of pixels with the same pixel value (date). The total burned area for individual fires was computed as the sum of the daily burned areas. The annual burned area for the study area was 
computed as the sum of burned area of individual fires during a given year. Burned areas were calculated after subtracting the unburned island areas as defined by the dNBR mask. For the set of largest fires accounting for $95 \%$ of the Alaska LFDB burned area during the study period, unburned islands accounted for $15 \%$ of the total perimeter area.

\subsubsection{Vapor pressure deficit}

Vapor pressure deficit (VPD) represents the difference between the saturation vapor pressure and the actual vapor pressure. The VPD compresses meteorological information about the drivers of evaporative demand by the atmosphere into a single variable and can be easily calculated from meteorological variables in existing reanalysis data sets (Bonan, 2008). VPD has been previously used to characterize tree physiology in boreal ecosystems (Zimmermann et al., 2000; Angstmann et al., 2012). It has also been used to analyze fire regimes under various climatic conditions in forest ecosystems (Balch et al., 2008) and as predictor variable in regional and global fire models (Pechony and Shindell, 2009; Silvestrini et al., 2011). We calculated VPD from the air temperature and relative humidity (\%) using the 2 meter variables in the NARR data set. VPD was calculated with the following expressions (Bonan, 2008):

$$
\begin{aligned}
& \mathrm{SVP}=610.7 \times 10^{7.5 \cdot T /(237.3+T)} \\
& \mathrm{VPD}=(100-\mathrm{RH}) \cdot \mathrm{SVP},
\end{aligned}
$$

Where saturation vapor pressure (SVP) is the saturation vapor pressure, $T$ is surface air temperature $\left({ }^{\circ} \mathrm{C}\right)$, and $R H$ is the relative humidity. To reduce the data volume a single $3 \mathrm{~h}$ NARR record corresponding to the 00:00-03:00 UTC time interval (15:00-18:00 p.m. Alaska time) was compared to the daily fire variables described above. Since the NARR records provide variable averages for $3 \mathrm{~h}$ cycles and the longitudinal range of the area of study accounts for variations in local time of less than 2 hours, local time was not dynamically adjusted.

For each VPD pixel, we computed a daily average for the 33 year period to serve as the baseline value for the calculation of VPD anomalies. The daily VPD maps were further compressed to produce a time series of area-weighted average daily VPD within the study domain shown in Fig. 1. Subsequently the regional time series also were combined to produce a 33 year average to enable the calculation of regional VPD anomalies within our study region.

The spatial resolution of the VPD images was $32 \mathrm{~km}$, the same resolution as the underlying NARR driver variables. For each fire, a time series of daily VPD values was constructed by extracting the pixels overlaying the entire fire perimeter. If more than one VPD pixel overlaid the fire perimeter, the average value of all VPD pixels was calculated. Since the spatial resolution of the daily VPD maps was significantly coarser than that of the fire perimeters, these VPD time series described only the general meteorological conditions near the fire front, and did not capture not finer scale variations caused by topography, fire-driven weather, or other processes.

\subsubsection{Time and location of lightning-induced ignitions}

To identify lightning-related fire ignitions the ALDN, we used the following approach. First, for each fire, we defined a $1.5 \mathrm{~km}$ radius neighborhood as around the $1 \mathrm{~km}$ location of the first active fire detected within each fire perimeter. Any lightning strikes occurring during the same day or the day before of the active fire observation were classified as lightning that triggered a fire ignition. All other lightning observations were classified as those that did not trigger an ignition. The annual average VPD values at the location and time of the lightning-related fire ignitions were computed and compared against the annual average VPD values of all others lightning strikes through a test of significance ( $z$ test).

We only considered the first ignition point within each fire. Some large fires may have had secondary ignition points. To investigate their prevalence, we searched for active fires further than $10 \mathrm{~km}$ from existing fire front and classified these pixels as possible secondary ignitions. This analysis indicated that eight fires during the period 2002-2011 (1.8\% of the total number of fires) had possible secondary ignitions.

\section{Results}

\subsection{VPD influence on ignition and initial fire spread}

The number of lightning strikes varied considerably from year to year (Fig. 3a). The years with the highest number of recorded lightning strikes corresponded to years with the largest burned area, with an $R^{2}$ of $0.52(P<0.01)$. Most lightning strikes occurred during June and July, with these months combined accounting for $89 \%$ of the lightning strikes during 2002-2012. Most of the lightning outside of this period occurred during May (3.8\%) or August and September (6.9\%) (Fig. 3a). For each year between 2002 and 2011 daily VPD values during lightning strikes leading to fire ignitions were significantly higher than VPD values for all other lightning strikes ( $z$ test, 0.05 significance level) (Fig. 3b). The seasonal pattern of fire start dates followed a similar pattern to that of lightning strikes, with fires less clustered in the central summer months (Fig. 3c). The majority (72\%) of the lightning-induced fires occurred in June and July, $14 \%$ in May and 13\% in August and September. The total number of annual lightning strikes was significantly related to the number of lightning-induced fires $\left(R^{2}=0.63\right.$, $n=10, p=0.01)$ and the total number of fires $\left(R^{2}=0.44\right.$, $n=10, p=0.01$ ) (Fig. 3d).

To identify the influence of meteorology on fires of various sizes we grouped fires in four categories: small fires $(0$ $1000 \mathrm{ha})$; medium fires (1000-10000 ha); large fires (10 000 $50000 \mathrm{ha}$ ); and very large fires (>50000 ha). The analysis revealed that fire lengths varied from a single day to nearly 

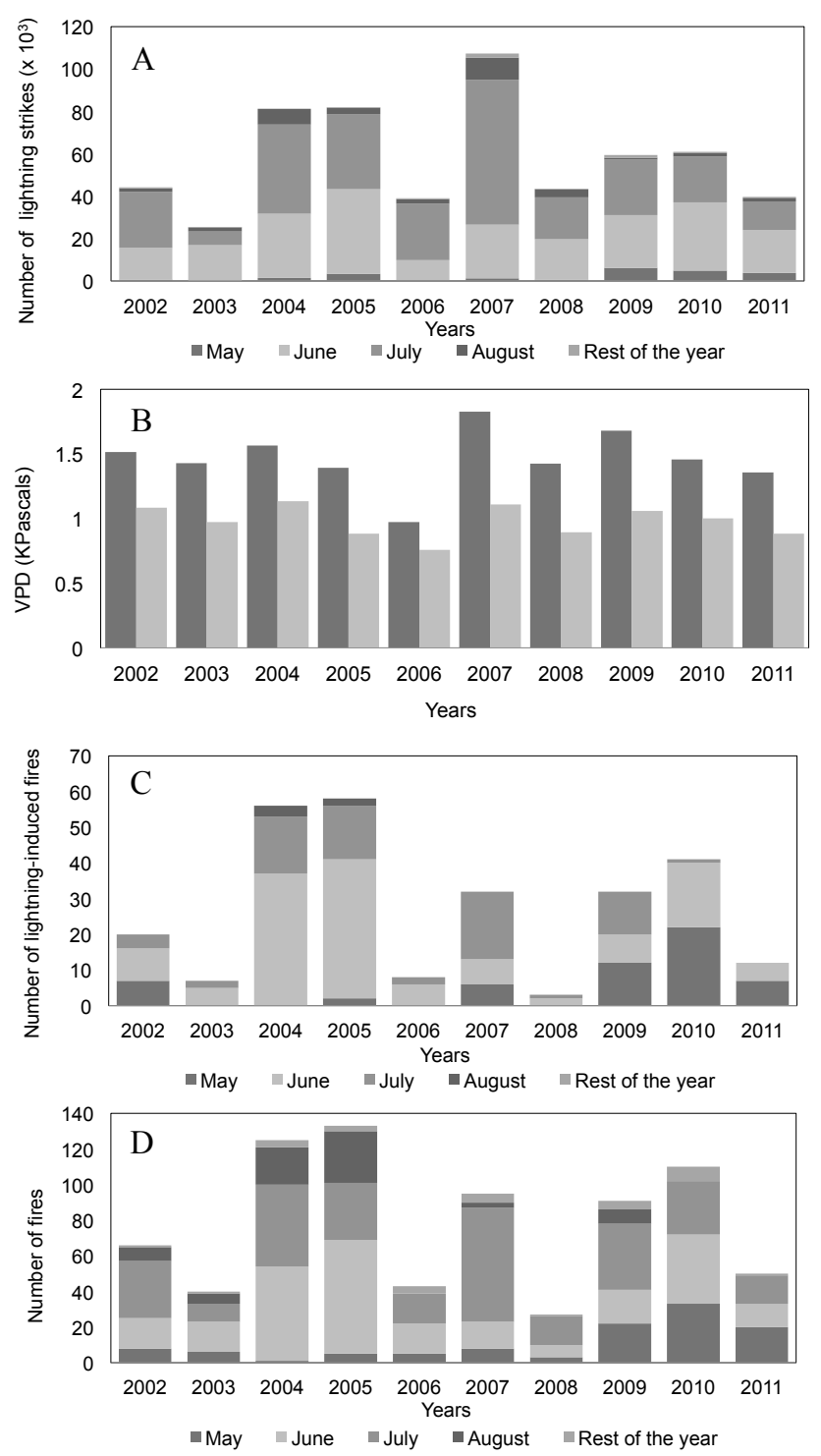

Figure 3. (A) Annual number of lightning strikes from ALDN disaggregated by month in the period 2002-2011; (B) Average VPD values for lightning strikes leading to fire ignitions (dark grey) and average VPD values for all other lightning strikes (light grey). (C) Annual number of lightning-induced fire start dates disaggregated by month in the period 2002-2011. (D) Annual number of fires fire start dates disaggregated by month during 2002-2011.

90 days. A positive relationship existed between fire duration and fire size (Fig. 4). Many small fires persisted for a few days and were often characterized by an initial period of limited growth (low daily burned area) followed by an extinction during the first period of negative VPD anomalies. In a few cases small fires were dormant for longer periods, and then began to grow after several weeks.

For all of the different fire size classes, mean VPD anomalies averaged 1-5 days prior to ignition were positive, indicating that lower fuel moisture levels had a significant posi-

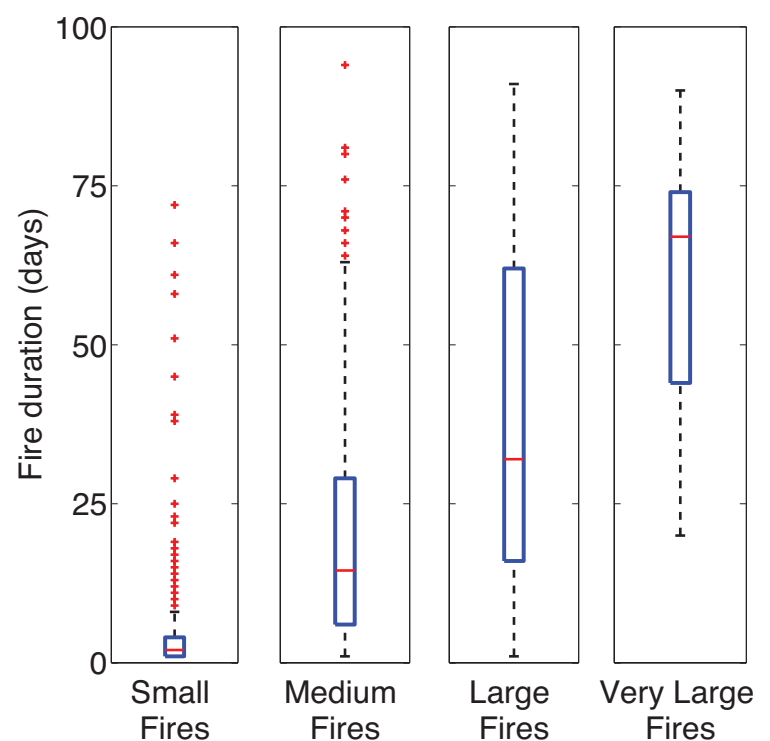

Figure 4. Relationship fire duration and fire size: Small fires were defined as having sizes between ( $0-1000$ ha, medium fires between 1000-10000 ha, large fires between 10000-50000) ha, and very large fires as greater than 50000 ha. The percentage of number of fires and burned area for each group was respectively $63.5 \%$ and $2 \%$ for small fires; $24.3 \%$ and $18 \%$ for medium fires; $10 \%$ and $39.9 \%$ for large fires; and $2.7 \%$ and $40 \%$ for very large fires.

tive influence on lightning triggered ignition. These positive VPD anomalies, however, were not significantly different as a function of fire size, providing evidence that pre-ignition conditions did not play an important role in determining the size of the final fire perimeter (Fig. 5a). In contrast, VPD anomalies in the first 5 days after ignition were significantly related to fire size. The VPD anomalies in this period were negative for small fires, and were positive and considerably higher both for large and very large fires (Fig. 5b). These results imply that meteorological conditions immediately following ignition are crucial for the growth of large wildland fires. Small fires tended to occur during oscillating VPD conditions under which the fires were unable to grow and eventually were extinguished during periods of wet weather. In contrast, sustained periods of positive VPD anomalies immediately after ignition may have contributed to the resilience of fires that eventually grew to very large sizes. One possible mechanism for this diverging fire behavior might be the establishment of larger fire perimeters for fires with a higher initial VPD, thus creating the potential for a larger number of surface or subsurface hot spots. These hot spots may allow this class of fires to survive during relatively long periods of wet weather, and then expand later when the climate is more favorable for fire spread. Qualitative evidence for this hypothesis is provided in Fig. 6. For many of the larger fires during 2004, 2005, and 2009, long quiescent intervals preceded periods of rapid burned area growth in mid or late summer. 

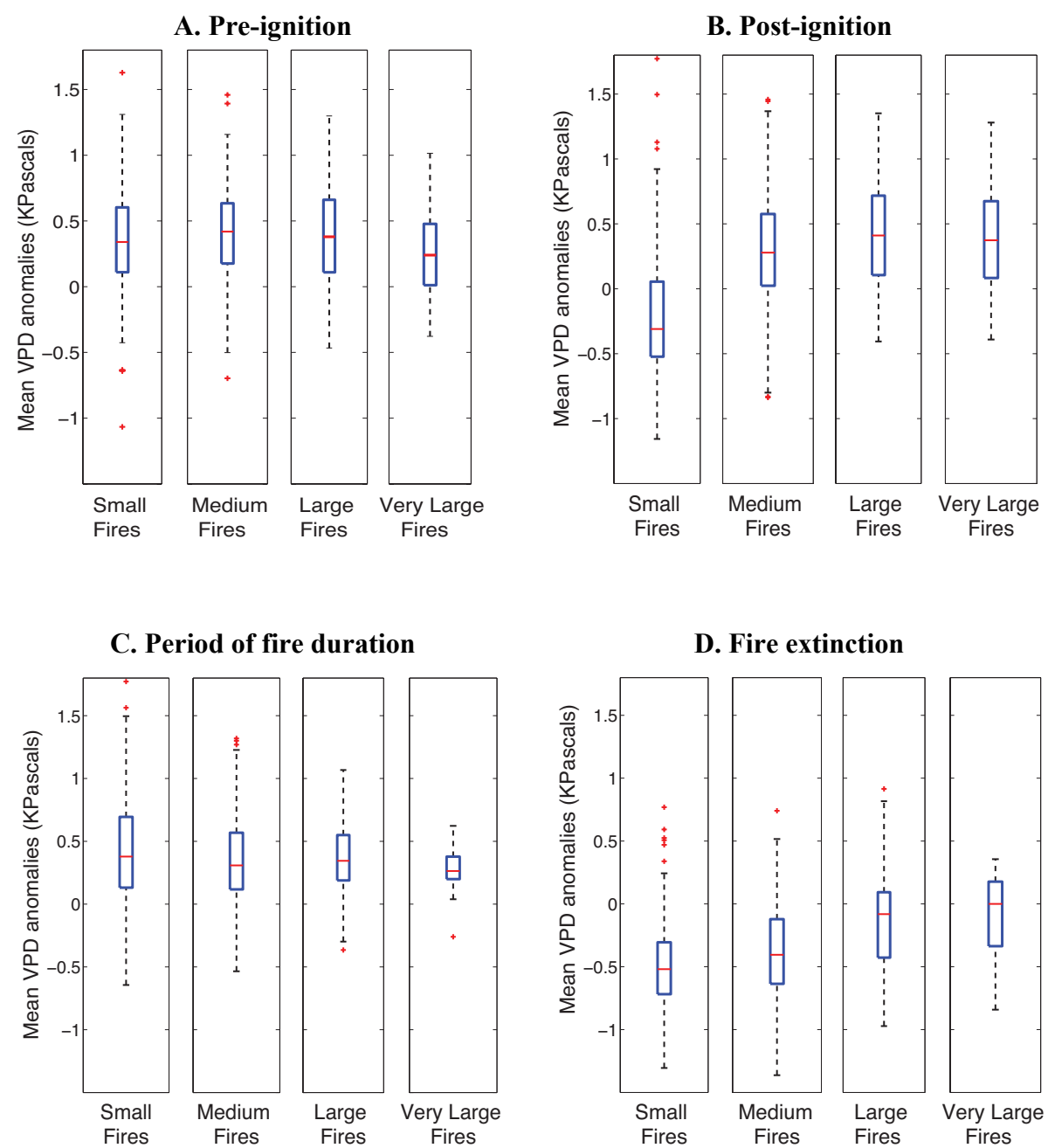

Figure 5. Relationship between VPD anomalies and fire size for different phases of fire growth. Mean VPD anomalies are shown for A) prior to ignition, averaged over 1-5 days before the ignition event, B) immediately after ignition, averaged over 1-5 days after the ignition event, C) during the duration of each fire (i.e., between the ignition and extinction events), and (D) during extinction, defined as the 1-5 days after the last satellite active fire observation was detected within or near the fire perimeter. Mean VPD anomalies for fire size classes were significantly different ( $z$ test, 0.05 significance level).

\subsection{VPD influence on the burned area of individual fires}

Vapor pressure deficit was positively correlated with both daily fire spread and the final size of individual fires. Time series of daily burned areas for large fires were significantly correlated with daily VPD anomalies. For the 160 fires greater than 5000 ha in our 2002-2011 data set, correlation coefficients between VPD anomalies and daily burned area varied between 0.03 and 0.77 , with a mean of 0.14 . This set of fires had a mean duration of 39 days and accounted for 90 percent of the burned area during 2002-2011. Examples of these relationships for 4 large fires during 2004, including the Boundary, Dall City, Winter Trail, and Billy Creek fires are shown in Fig. 7. Daily fire spreads were often highly variable within the same fire, alternating between periods of large daily fire spread and long periods of quiescence (Figs. 6 and 7). Positive VPD anomalies averaged over fire lifetimes were positive and without significant differences for the different group sizes (Fig. 5c), indicating that drier than normal atmospheric conditions contributed to sustained rates of fire spread. Cumulative VPD anomalies during the lifetime of each fire in this subset explained $60 \%$ of the variance in final fire size (Fig. 8). These results provide evidence that after ignition, the persistence of extended periods with positive VPD anomalies contributed to the growth of fires with larger sizes. Fire extinctions also occurred for many fires during periods with negative VPD anomalies. Mean VPD anomalies during the fire extinction, defined as the 5 days after the last recorded active fire, were negative for all fire sizes, with lower (more negative) values for smaller fires (Fig. $5 \mathrm{~d}$ ). Since larger fires often persisted into August when monthly mean VPD levels were lower, their extinction may require a less 
(a)
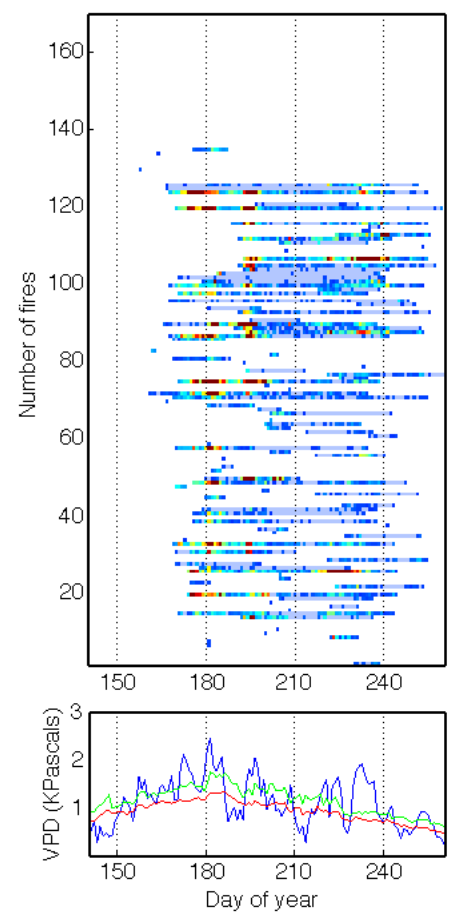

(b)
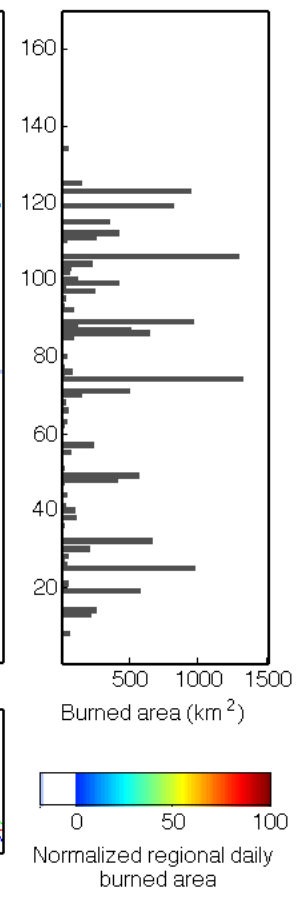
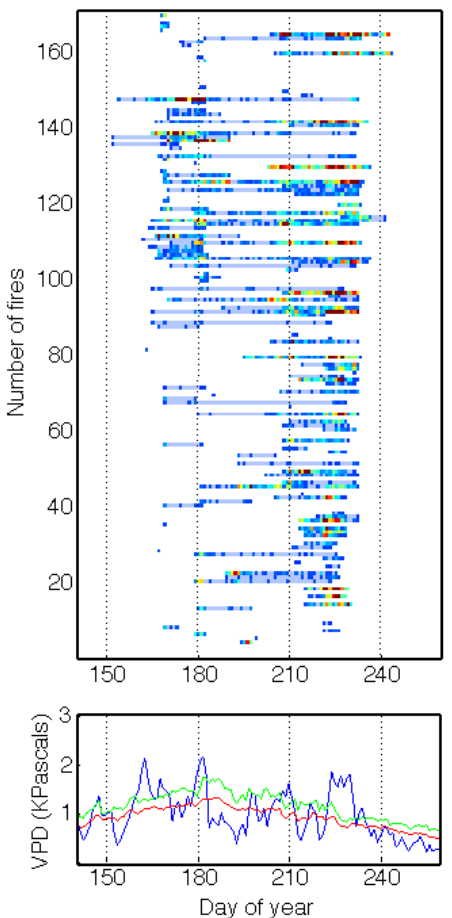

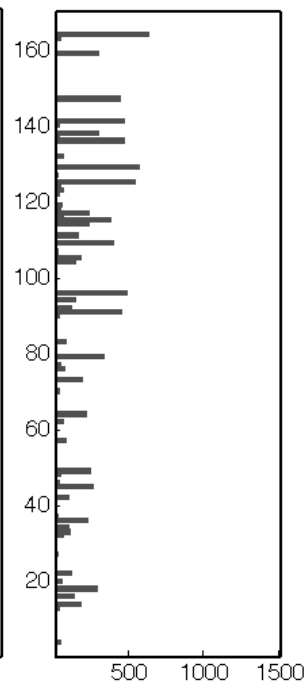

Burned area $\left(\mathrm{km}^{2}\right)$

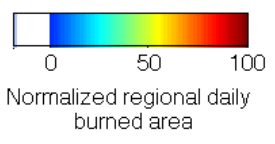

(b)

2009
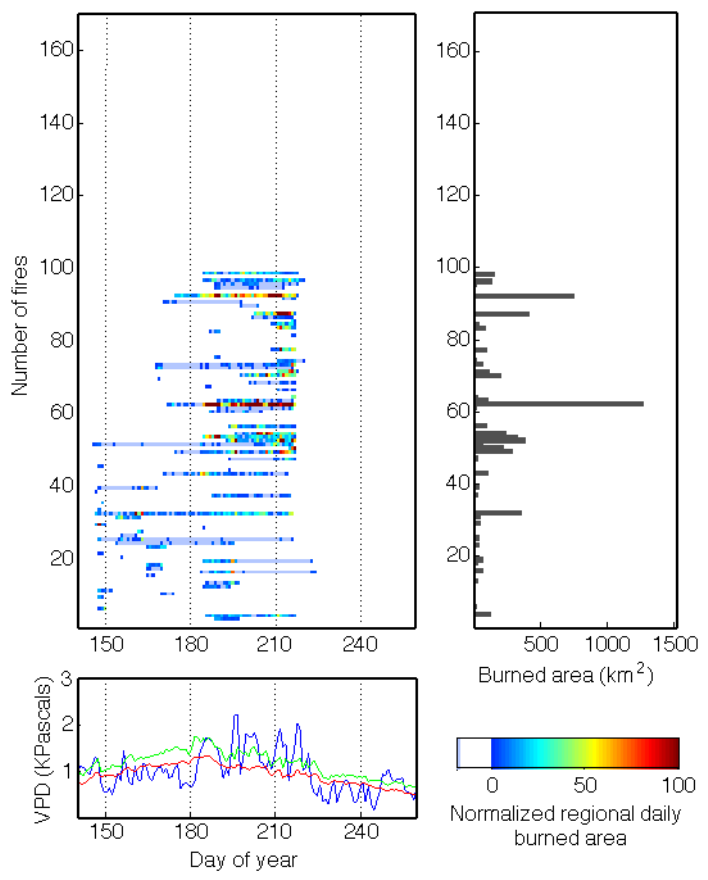

Figure 6. Top plate: length and daily burned area of individual fires in 2004, 2005 and 2009. Each line represents a recorded fire event in each year. Fires are organized from north (top) to south (bottom) within the study domain. The color bar represents daily burned area, with values normalized by annual regional daily burned area values between 0 and 100. Light blue (color code -20) represents days between ignition and extinction in which burned area was not registered. Bottom plate: daily VPD values averaged for interior Alaska (blue), 1979-2011 daily VPD average (red) and 75th percentile values in the period 1979-2011 (green). Interior Alaska was defined by the longitudes $142^{\circ}-154^{\circ}$ West and latitudes $63.5^{\circ}-67.5^{\circ}$ North. The horizontal axes in both plates represent the day of the year. 

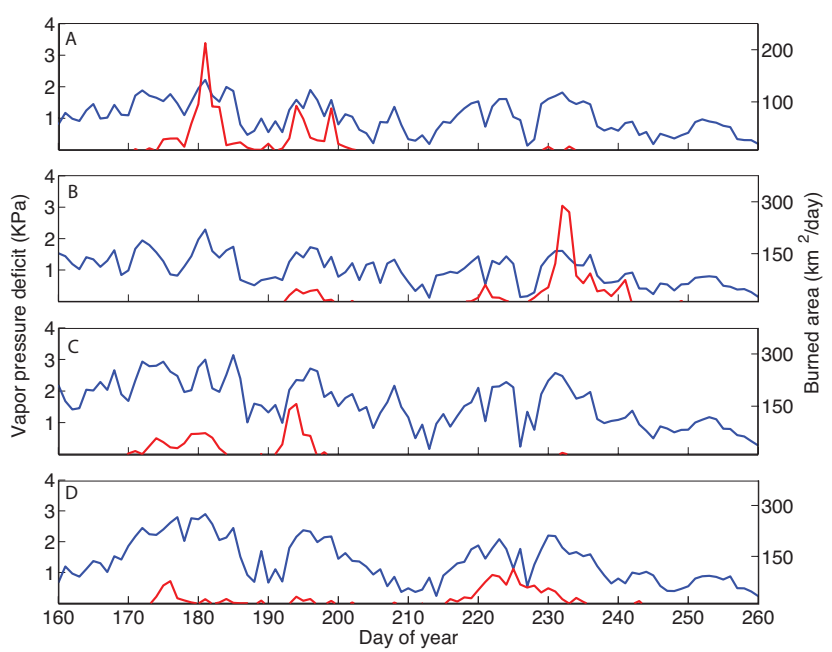

Figure 7. Time series of VPD and burned area for four large fires in 2004: (A) Boundary, (B) Dall City, (C) Winter Trail, and (D) Billy Creek. Daily VPD are shown with the blue line, daily burned area (in $\mathrm{km}^{2}$ per day) with the red line, and fire duration with the black line near the top of each panel.

intense period of wet weather than smaller fires that are extinguished in mid-summer.

\subsection{VPD influence on regional burned area}

For many fires in interior Alaska, the timing of dry and wet periods during the fire season was similar. For example, for the four fires shown in Fig. 7, many of the high and low VPD periods occurred at similar time intervals, even though these fires were located in different parts of the state. As a consequence of the regional coherence in meteorology, ignition, daily fire spread, and fire extinction periods were often synchronized across different fires. In Fig. 6a, b and c, for example, the end of the 2005 fire season occurred abruptly as a negative VPD anomaly extinguished almost all of the fires across the state between days 230 and 240. In 2009, the end of the fire season was also abrupt in the northern part of the state, and occurred about 15 days earlier than in 2005. Ignitions appeared less synchronized than extinctions, but also showed distinct temporal clusters in different years (Fig. 6).

The correlation between daily VPD and daily burned area, averaged at a regional level, varied from year to year, with stronger positive correlations observed in general during high fire years and weaker correlations observed in low fire years (Table 2). Large positive VPD anomalies that persisted for 10 days or more during 2002, 2004, 2005, and 2009 fire seasons were responsible for most of the burned area during the decade (Fig. 9). Periods with positive VPD anomalies accounted for $79 \%$ of the total regional burned area during $2002-2011$, yet accounted for only $40 \%$ of the time during the fire season (Fig. 9).

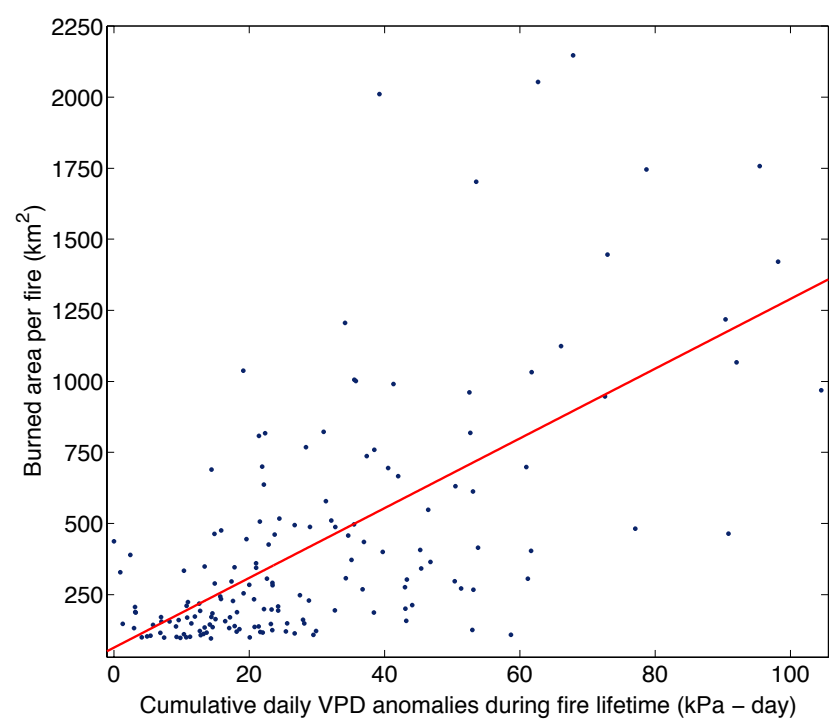

Figure 8. Sum of positive VPD anomalies during a fire lifespan against burned area per fire. This figure includes all fires in the period 2002-2011 with a duration greater than 1 day $R^{2}($ Linear fit $)=$ 0.60 .

\section{VPD influence on interannual variability of regional burned area}

The relationships with VPD identified above for individual fires and for regional burned area during individual fire seasons allowed us to develop hypotheses about climate drivers of interannual variability in wildfire activity. We hypothesized specifically, that years with more positive summer VPD anomalies would have higher levels of cumulative burned area because these drier conditions would facilitate more ignitions and allow for longer intervals when fire spread was high. During our study period of 2002-2011, we found a significant positive correlation between the sum of positive VPD anomalies during the fire season (DOY 150-240) and annual burned area $\left(R^{2}=0.841, n=10, p<0.01\right)$ for the 20022011 period. The correlation was weaker but still highly significant for the longer 1979-2011 period of the NARR data set $\left(R^{2}=0.45, n=33, p<0.01\right)$ (Fig. 10). These relationships supported our hypothesis and provided evidence that VPD was a key driver of regional fire dynamics on longer timescales.

We also investigated how year-to-year changes in the seasonal timing of fire ignitions and fire extinctions contributed to interannual variability in regional burned area. The mean annual ignition dates varied from early June (DOY 175) to mid-July (DOY 191) (Table 1). Early annual ignition dates corresponded to large annual burned area years $\left(R^{2}=0.58\right.$, $n=10, p=0.01)$. The mean extinction dates ranged from early June (DOY 172) to early September (DOY 221), and had a significant positive correlation with annual burned area $\left(R^{2}=0.82, n=10, p=0.01\right)$. Mean fire season duration, 
Table 1. Number of fires, mean and standard deviation (SD) ignition and extinction dates and mean fire season duration.

\begin{tabular}{ccccccc}
\hline Year & $\begin{array}{c}\text { Number } \\
\text { of fires }\end{array}$ & $\begin{array}{c}\text { Mean } \\
\text { ignition } \\
\text { date }\end{array}$ & SD & $\begin{array}{c}\text { Mean } \\
\text { extinction } \\
\text { date }\end{array}$ & $\begin{array}{c}\text { SD } \\
\text { Mean fire } \\
\text { season } \\
\text { duration } \\
\text { (days) }\end{array}$ \\
\hline 2002 & 83 & 186 & 25 & 204 & 23 & 18 \\
2003 & 41 & 175 & 21 & 183 & 28 & 9 \\
2004 & 134 & 191 & 22 & 221 & 27 & 30 \\
2005 & 170 & 186 & 24 & 206 & 29 & 19 \\
2006 & 32 & 179 & 17 & 185 & 19 & 6 \\
2007 & 110 & 184 & 19 & 193 & 22 & 9 \\
2008 & 49 & 183 & 20 & 194 & 28 & 11 \\
2009 & 99 & 175 & 24 & 191 & 30 & 16 \\
2010 & 171 & 167 & 25 & 177 & 31 & 10 \\
2011 & 61 & 166 & 22 & 172 & 21 & 6 \\
\hline
\end{tabular}

Burned area $\left(\mathrm{km}^{2}\right)$.

Table 2. Annual VPD summer average 1 (June-August), slope of the burned area-VPD relationship and $r$ squared.

\begin{tabular}{cccccc}
\hline Year & $\begin{array}{c}\text { Burned } \\
\text { area }\left(\mathrm{km}^{2}\right)\end{array}$ & $\begin{array}{c}\text { Number } \\
\text { of fires }\end{array}$ & $\begin{array}{c}\text { VPD } \\
\text { Summer } \\
\text { Average } \\
(\mathrm{kPa})\end{array}$ & $\begin{array}{c}\text { Burned } \\
\text { Area-VPD } \\
\text { slope }\end{array}$ & $\begin{array}{c}\mathrm{R} \\
\text { squared }\end{array}$ \\
\hline 2002 & 7036 & 63 & 0.733 & 3482 & 0.38 \\
2003 & 1757 & 29 & 0.643 & 1207 & 0.29 \\
2004 & 22497 & 108 & 0.900 & 11086 & 0.50 \\
2005 & 16752 & 141 & 0.782 & 9490 & 0.30 \\
2006 & 772 & 18 & 0.523 & 448 & 0.08 \\
2007 & 2191 & 71 & 0.765 & 861 & 0.11 \\
2008 & 299 & 21 & 0.572 & 325 & 0.26 \\
2009 & 10045 & 81 & 0.749 & 4806 & 0.12 \\
2010 & 3271 & 99 & 0.616 & 2096 & 0.41 \\
2011 & 1219 & 41 & 0.554 & 990 & 0.26 \\
\hline
\end{tabular}

defined as the difference between annual mean extinction and ignition dates varied from 6 to 30 days (Table 1), and there was a strong positive relationship between mean fire duration and annual burned area $\left(R^{2}=0.94, n=10, p=0.01\right)$ (Fig. 11).

\subsection{Implications of meteorological controls for fire management}

Each year, some of the fires ignited in late spring or early summer remained dormant for extended periods until more extreme periods of high fire weather caused these perimeters to rapidly grow (Fig. 6). Other fires were ignited during periods of sustained dry conditions, and rapidly expanded within a few days of the initial lightning strike. Fires that remain dormant for extended periods may represent a target of opportunity for fire suppression efforts and the design of fire management strategies, given large unidirectional changes in burned area expected from climate warming. To investigate the importance of these different fire types in contributing
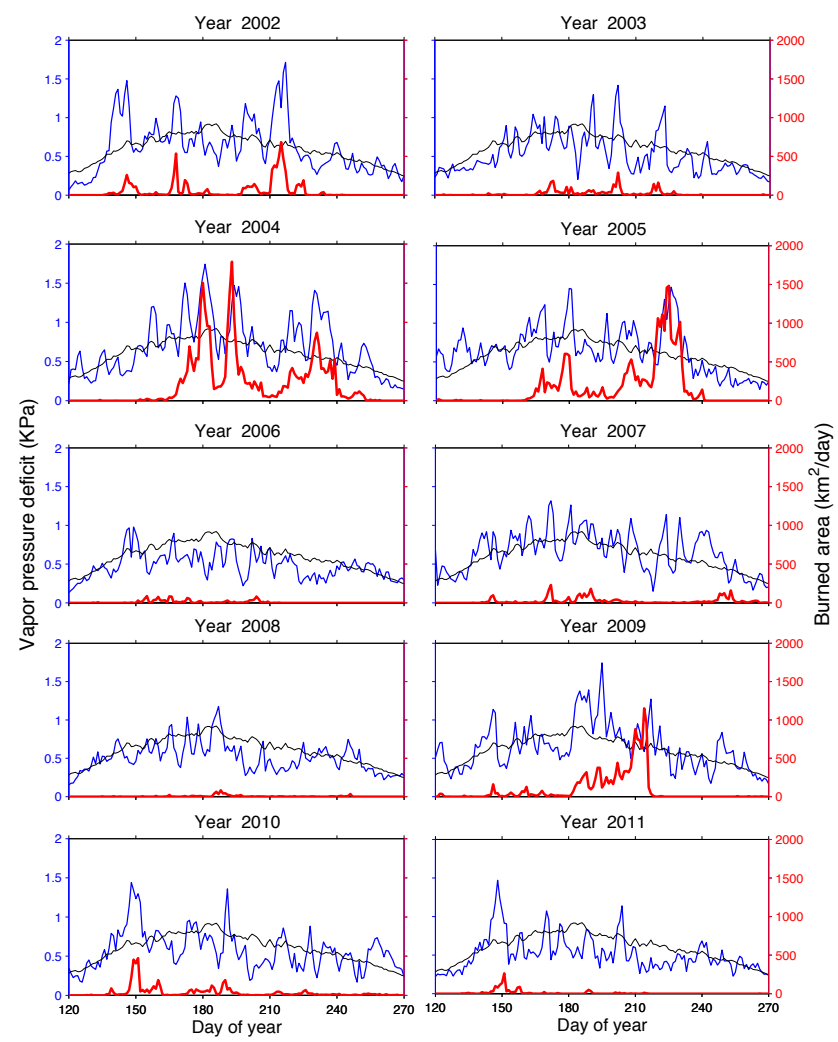

Figure 9. Times series of daily VPD (blue; left axis) and burned area (red; right axis) for interior Alaska. Domain-wide mean annual daily VPD from 1979-2011 is also shown in black (left axis).

to annual burned area, we conducted the following analysis. First, we quantified the number of fires that stayed below a certain size threshold (5000 ha) for the first 10 days after ignition. From the 160 fires that consumed more than 5000 ha during 2002-2011, 61 fires required more than 10 days after ignition to reach this area threshold. These fires accounted for $30 \%$ of the total burned area during the period. We also analyzed the 50 largest fires within the study domain during this interval. These fires accounted for $69 \%$ of the total burned area during 2002-2011. For this set, 23 fires remained below a threshold of 5000 ha during the first 10 days after ignition, and 32 fires burned less than $20 \%$ of their total size during the first 10 days after ignition (Fig. 12). Fires that initially remain in a quiescent/smoldering phase could be targeted for suppression, although as described below more information is needed to identify landscape characteristics that enable fires within this class to grow to very large sizes. 


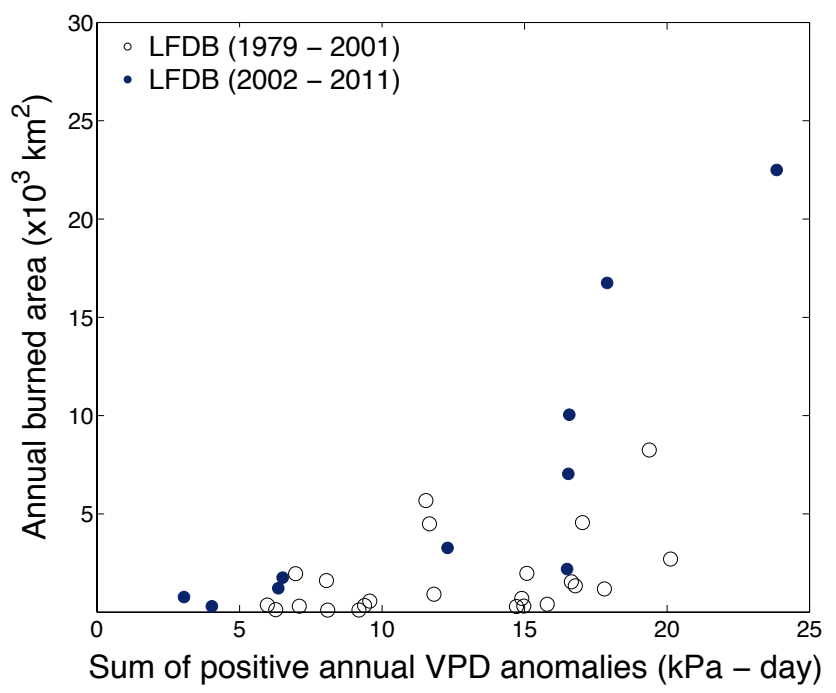

Figure 10. Scatterplot of the sum of positive VPD anomalies during DOY 150-240 against annual burned area for 2002-2011 (blue dots) extracted from Alaska LFDB and subtracting unburnt islands within fire perimeters and 1979-2001 (black asterisks) from the Alaska LFDB.

\section{Discussion}

\subsection{VPD, satellite-based information and fire danger estimation}

We found strong positive relationships between VPD and burned area at different temporal and spatial scales. This relationship was observed at a fine temporal resolution (daily VPD versus daily burned area) for individual fires, at a regional level within a single fire season, and across different years for the study domain as a whole. VPD also was implicated as an important climate regulator during multiple fire stages including, specifically, the probability that a lightning strike triggered ignition, during periods of initial fire spread, for daily burned area variations in larger fires, and the timing of fire extinction.

Our findings suggest that by combining satellite estimates of fire spread with high-resolution climate information, there is potential to improve fire weather systems and fire behavior models. Several fire danger and fire behavior weather systems for forests were developed, for example, before satellite information was widely accessible. For instance the Canadian Forest Fire Weather Index (FFWI) system (Van Wagner, 1987) uses weather variables interpolated from weather stations to estimate six empirical indices related to soil moisture and fire behavior. Large data sets of fire spread, such as those produced here in a systematic way from MODIS data, may enable the optimization of some of these terms. For example, climate controls on rates of initial spread, encapsulated by the Initial Spread Index (ISI) in the FFWI system could be targeted for refinement by harvesting daily burned area

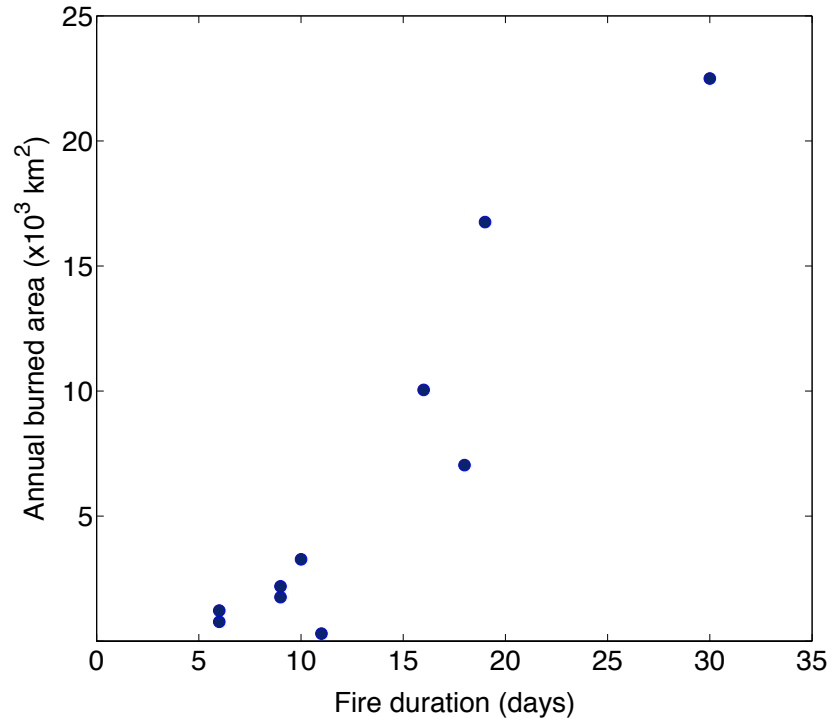

Figure 11. Scatterplot of fire season length against annual burned area for 2002-2011 extracted from Alaska LFDB and subtracting unburnt islands within fire perimeters.

rates immediately following ignition, and combining this information with meteorology observations. More generally, daily burned area observations such as the time series created here may enable the development of better parameterized and more mechanistic models of fire behavior and fire spread (e.g., FARSITE, (Finney, 2004)).

\subsection{Implications for Earth system models}

Knowledge of fire-spread dynamics in boreal forests is fundamental for developing realistic projections of burned area for different climate change scenarios. Models of terrestrial carbon dynamics in boreal ecosystems rely on future burned area estimates at a regional level (Mann et al, 2012; Balshi et al.; 2007; Balshi et al., 2009). These estimates are commonly based on linear relationships between monthly meteorological variables and burned area. Duffy et al. (2005), for example, applied the average June temperature as a predictor of burned area at a regional level. Bachelet et al. (2005) modeled burned area as a function of a drought index within a global vegetation model to study carbon dynamics in Alaska. Rupp et al. (2007) estimated burned area using an empirical relationship driven by growing-season average temperature and cumulative precipitation, and integrated this information within a landscape-level model of vegetation dynamics. Several studies have explored the relationships between fire weather indices and burned areas to predict future burned area using climate model simulations of the 20th and 21 st centuries (Flannigan et al., 2005; Balshi et al., 2009; De Groot et al., 2013).

Our results show that multiple interacting mechanisms likely govern the emergent relationships observed between 
climate and burned area at coarser spatial and temporal scales. Large fires commonly last for several weeks, alternating periods of high activity and dormancy associated with VPD dynamics. Our analysis suggests that the potential for extreme high fire years is greater when several environmental factors align. First, if an above average number of lightning storms and drier than normal conditions occur during May and June, this may create an anomalously high number of fire ignitions during the early part of the fire season. If some of these storms are followed by several days of dry weather, this increases the probability that some of the ignitions will grow past some minimum size that increases their chances for survival during subsequent wet periods. In the middle of the growing season, more frequent and longer duration high pressure systems have the potential to create persistent periods of dry and hot weather that promote rapid rates of fire spread. Large, multi-day positive VPD anomalies occurred, for example, during both the 2004 and 2005 extreme fire seasons (Fig. 9). Finally, near the end of the fire season, climate conditions that are drier than average may reduce the probability of an early, region-wide extinction event. The influence of climate during these multiple phases of fire development are unlikely to be captured by monthly mean (or growing-season averaged) climate or weather indices, and thus an important direction for future work is to develop more sophisticated predictive models that take into account daily weather patterns and atmospheric processes that regulate convection and lightning storms. The inclusion of these processes in burned area models, along with better representation of ecosystem and topographic controls, may lead to improved estimates of climate-induced changes in regional burned area and carbon dynamics in Earth system models.

\subsection{Implications for fire management}

An improved understanding of the influence of meteorology on fires in boreal forests may create new opportunities for the design and implementation of fire suppression operations to maintain historical or current fire regimes. Today, the extent of the wildness area and limited access to many remote fires in interior Alaska increases costs for suppression. Fire suppression and management resources in Alaska are allocated based on risks to human settlements and ecosystems; the cost of suppression activities must be commensurate with the value of the resources needing protection (Alaska Interagency Wildland Fire Management Plan, 2010). Fire suppression activities are categorized in different management options in which areas with settlements and infrastructure receive the highest priority. However, given the magnitude of the estimated carbon pool in Alaskan boreal forests, the potential future implementation of international carbon tax mechanisms or other climate policies could justify more extensive fire suppression activities in the near future. Fire suppression may be even more valuable from the perspective of adaptive resource management: maintaining current burned
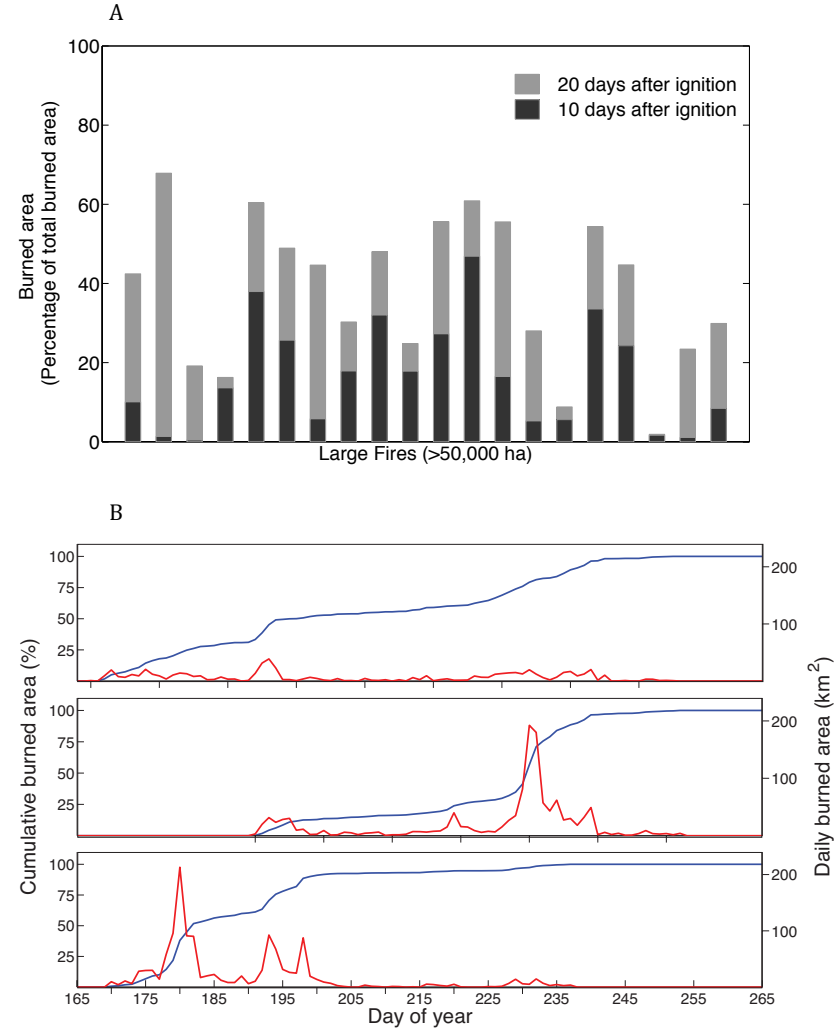

Figure 12. (A) Percentage of total burned area within 10 and 20 days after fire ignition for fires larger than 50000 ha during the period 2002-2011. (B) Time series of daily (red line) and cumulative burned area (blue line) for three large fires in 2004. The fire in the lower middle panel had burned less than $35 \%$ of its final burned area within the first 40 days after its ignition, which made it a suitable candidate for fire suppression.

area levels may slow changes in species composition and other changes in ecosystem function (i.e., permafrost thaw) expected with climate warming.

The development of decision systems including information on fire progression drivers, weather forecasts, environmental variables (including land cover, topography, and landscape fragmentation) have potential to improve the efficiency of fire suppression operations. As previously presented, some fires were ignited in late spring or early summer that remained dormant for extended periods until more extreme periods of high fire weather caused these perimeters to rapidly grow (Fig. 6). The discontinuous progression of some wildfires offers the opportunity to target selected fires that have the potential to grow to very large sizes and identify time windows in which suppression efforts could be implemented.

Large fires in Alaska account for a very significant share of the annual burned area. For instance, from a total of 134 fires (Table 1), the twenty largest fires of 2004 accounted for $80 \%$ of the annual burned area. Our analyses indicate that for more than half of the largest fires (32 out of 50) during the period 
2002-2011, less than $20 \%$ of their burned area occurred in the first 10 days after the ignition (Fig. 12). Increased fire suppression operations on fires with slow initial growth may be one strategy to slow increases in annual mean burned expected with climate warming. In this context, an important challenge for the future is to more effectively identify fires that represent ideal suppression opportunities based on their location and timing of ignition.

\subsection{Reducing Uncertainties in Future Work}

The bow-tie effect associated with large scanning angles of the MODIS sensor (Wolfe et al., 1998) can result in multiple detections of active fires, and represents an important source of uncertainty in the fire spread maps. While an operational routine to reduce multiple detections was not implemented in this study, filtering active fires by scan angle (and excluding observations at high scan angles) may serve as a means to reduce uncertainties in daily burned area estimates in future assessments. Further efforts to formally optimize other parameters in the inverse distance weighting interpolation may also yield improved estimates of fire progression.

Similarly, bidirectional reflectance distribution function (BRDF) effects can be potentially large at high latitudes and represent a source of uncertainties for the calculation of spectral indices. Here we used MODIS MOD13A1 surface reflectance composites to estimate dNBR in order to remove unburned islands. By using a relatively narrow temporal sampling window during summer, we attempted to minimize BRDF effects in this procedure. In future, use of the MODIS Nadir BRDF-Adjusted Reflectance (NBAR) product or Landsat imagery may increase algorithm performance, particularly if this work is coupled with more extensive ground truth analysis using field observations and higher resolution imagery.

Relationships between VDP and daily burned area observed here may have degraded in part by errors in the reanalysis product. More detailed work is needed in the future to investigate the sensitivity of these fire weather relationships to different types of meteorological observations. This will require a more systematic analysis of the quality of different reanalysis products in the region using available surface and tropospheric observations.

\section{Conclusions}

We combined MODIS active fires (MCD14ML) information, MODIS imagery (MOD13A1) and ancillary historic fire perimeter database (Alaska Large Fire Dataset) to produce a data set of fire-spread maps (daily burned area) in Alaska for the period of 2002-2011. This product allowed us to identify fire ignition location and dates and fire progression for individual wildfires. We used the fire spread maps with spatially and temporally explicit climate records to examine re- lationships between the driving gradient for vegetation water loss (VPD) and wildfire activity in boreal forest ecosystems. We found that VPD exerted considerable influence on burned area during multiple stages of fire growth, including ignition, initial rates of fire spread, daily burned area, and extinction. Lightning strikes that triggered fire ignitions occurred during a period with higher VPD. When VPD levels were above average in the first 5 days following ignition, final fire sizes were larger. Our analyses underline the importance of fine temporal patterns of VPD and lightning strikes and fire season length in regulating year-to-year variations in regional burned area. The findings of this study improve the spatial and temporal characterization of the climate processes regulating the contemporary fire disturbance regime and highlight in the importance of developing improved models to predict future changes in fire regimes. Information on fire progression of large wildfires may create potential opportunities for adaptive fire management in the future. The link between daily burned area from the fire spread maps and meteorological and landscape variables should allow for a more precise estimation of fire severity and fuel consumption and refine estimates of daily carbon emissions from boreal forest wildfires.

Acknowledgements. This work was supported by NASA's Carbon in Arctic Reservoirs Vulnerability Experiment (CARVE) Project. The authors would like to thank the anonymous reviewers for their valuable comments and suggestions to improve the quality of the paper.

Edited by: M. Williams

\section{References}

Abatzoglou, J. T. and Kolden, C. A.: Relative importance of weather and climate on wildfire growth in interior Alaska, Int. J. Wildland Fire, 20, 479-486, 2011.

Alaska Wildland Fire Coordinating Group: Alaska Interagency Fire Management Plan 2010, available at: http://fire.ak.blm.gov/ (last access: 26 August 2012), 2010.

Amiro, B. D., Todd, J. B., Wotton, B. M., Logan, K. A., Flannigan, M. D., Stocks, B. J., Mason, J. A., Martell, D. L., and Hirsch, K. G.: Direct carbon emissions from Canadian forest fires, 19591999, Can. J. Forest Res., 31, 512-525, 2001.

Amiro, B. D., Orchansky, A. L., Barr, A. G., Black, T. A., Chambers, S. D., Chapin III, F. S., Goulden, M. L., Litvak, M., Liu, H. P., McCaughey, J. H., McMillan, A., and Randerson, J. T.: The effect of post-fire stand age on the boreal forest energy balance, Agr. Forest Meteorol., 140, 41-50, 2006.

Amiro, B. D., Cantin, A., Flannigan, M. D., and de Groot, W. J.: Future emissions from Canadian boreal forest fires, Can. J. Forest Res., 39, 383-395, 2009.

Angstmann, J. L., Ewers, B. E., and Kwon, H.: Size-mediated tree transpiration along soil drainage gradients in a boreal black 
spruce forest wildfire chronosequences, Tree Physiol., 32, 599_ $611,2012$.

Bachelet, D., Lenihan, J., Neilson, R., Drapek, R., and Kittel, T.: Simulating the response of natural ecosystems and their fire regimes to climatic variability in Alaska, Can. J. Forest Res., 35, 2244-2257, 2011.

Balch, J. K., Nepstad, D. C., Brando, P. M., Curran, L. M., Portela, O., de Carvalho Jr., O., and Lefebvre, P.: Negative fire feedback in a transitional forest of southeastern Amazonia, Glob. Change Biol., 14, 2276-2287, 2008.

Balshi, M. S., McGuire, A. D., Zhuang, Q., Melillo, J., and Kicklighter, D. W.: The role historical fire disturbance in the carbon dynamics of the pan-boreal region: a process-based analysis, J. Geophys. Res., 112, G02029, doi:10.1029/2006JG000380, 2007.

Balshi, M. S., McGuire, A. D., Alshi, M. S., Mcguire, A. D., Duffy, P., Flannigan, M., Kicklighter, D. W., and Melillo, J.: Vulnerability of carbon storage in North American boreal forests to wildfires during the 21 st century, Glob. Change Biol., 15, 1491-1510, 2009a.

Balshi, M. S., McGuire, A. D., Duffy, P., Flannigan, M., Walsh, J., and Melillo, J.: Assessing the response of area burned to changing climate in western boreal North America using a Multivariate Adaptive Regression Splines (MARS) approach, Glob. Change Biol., 15, 578-600, 2009b.

Barrett, K., Kasischke, E. S., McGuire, A. D., Turetsky, M. R., and Kane, E. S.: Modeling fire severity in black spruce stands in the Alaskan boreal forest using spectral and non-spectral geospatial data, Remote Sens. Environ., 114, 1494-1503, 2010.

Barrett, K., McGuire, A. D., Hoy, E. E., and Kasischke, E. S.: Potential shifts in dominant forest cover in interior Alaska driven by variations in fire severity, Ecol. Appl., 21, 2380-2396, 2011.

Beck, P. S. A. and Goetz, S. J.: Satellite observations of high northern latitude vegetation productivity changes between 1982 and 2008: ecological variability and regional differences, Environ. Res. Lett., 6, 045501, doi:10.1088/1748-3182/6/4/049501, 2011.

Bond-Lamberty, B., Peckham, S. D., Ahl, D. E., and Gower, S. T.: Fire as the dominant driver of central Canadian boreal forest carbon balance, Nature, 450, 89-92, 2007.

Boby, L. A., Schuur, E. A. G., Mack, M. C., Verbyla, D., and Johnstone, J. F.: Quantifying fire severity, carbon, and nitrogen emissions in Alaska's boreal forest, Ecol. Appl., 20, 1633-1647, 2010.

Bonan, G.: Ecological Meteorology, Cambridge University Press, 201 pp., 2008.

Boschetti, L., Roy, D., Justice, C., and Giglio, L.: Global assessment of the temporal reporting accuracy and precision of the MODIS burned area product, Int. J. Wildland Fire, 19, 705-709, 2010.

Chapin, F. S., Callaghan, T. V., Bergeron, Y., Fukuda, M., Johnstone, J. F., Juday, G., and Zimov, S. A.: Global change and the boreal forest: thresholds, shifting states or gradual change?, Ambio, 33, 361-365, 2004.

Chen, F. and Liu, C.: Estimation of the spatial rainfall distribution using inverse distance weighting (IDW) in the middle of Taiwan, Paddy and Water Environment, 10, 209-222, 2012.

De Groot, W. J., Pritchard, J. M., and Lynham, T. J.: Forest floor fuel consumption and carbon emissions in Canadian boreal forest fires, Can. J. Forest Res., 392, 367-382, 2009.
De Groot, W. J., Flannigan, M. D., and Cantin, A. S.: Climate change impacts on future boreal fire regimes, Forest Ecol. Manag., 294, 35-44, 2013.

De Santis, A. and Chuvieco, E.: Burn severity estimation from remotely sensed data: performance of simulation vs. empirical models, Remote Sens. Environ., 108, 422-435, 2007.

Didari, S., Zand-Parsa, S., Sepakhah, A., Kamgar-Haghighi, A., and Khalili, D.: Preparation of frost atlas using different interpolation methods in a semiarid region of south of Iran, Theor. Appl. Climatol., 108, 159-171, 2012.

Dissing, D. and Vervyla, D. L.: Spatial patterns of lightning strikes in interior Alaska and their relations to elevation and vegetation, Can. J. Forest Res., 33, 770-782, 2003.

Duffy, P. A., Walsh, J. E., Graham, J. M., Mann, D. H., and Rupp, T. S.: Impacts of large-scale atmospheric-ocean variability on Alaskan fire season severity, Ecol. Appl., 15, 1317-1330, 2005.

Dyrness, C. T. and Norum, R. A.: The effects of experimental fires on black spruce forest floors in interior Alaska, Can. J. Forest Res., 13, 879-893, 1983.

Epting, J., Verbyla, D., and Sorbel, B.: Evaluation of remotely sensed indices for assessing burn severity in interior Alaska using Landsat TM and ETM+, Remote Sens. Environ., 96, 328-339, 2005.

Finney, M. A.: FARSITE: Fire Area Simulator-model development and evaluation. Research Paper RMRS-RP-4 Revised. Ogden, UT: U.S. Department of Agriculture, Forest Service, Rocky Mountain Research Station, 2004.

Flannigan, M. D., Logan, K. A., Amiro, B. D., Skinner, W. R., and Stocks, B. J.: Future area burned in Canada, Climatic Change, 72, 1-16, 2005.

French, N. H. F., Kasischke, E. S., Stocks, B. J., Mudd, J. P., Martel, D. L., and Lee, B. S.: Carbon release from fires in the North American boreal forest, in: Fire, Climate Change and Carbon Cycling in the North American Boreal Forest, edited by: Kasischke, E. S. and Stocks, B. J., Springer, New York, 377-388, 2000.

French, N. H. F., Goovaerts, P., and Kasischke, E. S.: Uncertainty in estimating carbon emissions from boreal forest fires, J. Geophys. Res., 109, D14S08, doi:10.1029/2003JD003635, 2004.

French, N. H. F., Groot, W. J. D., Jenkins, L. K., Rogers, B. M., Alvarado, E., Amiro, B., Jong, B. D., Goetz, S., Hoy, E., Hyer, E., Keane, R., Law, B. E., McKenzie, D., McNulty, S. G., Ottmar, R., Perez-Salicrup, D. R., Randerson, J., Robertson, K. M., and Turetsky, M.: Model comparisons for estimating carbon emissions from North American wildland fire, J. Geophys. Res., 116, G00K05, doi:10.1029/2010JG001469, 2011.

Giglio, L., Descloitres, J., Justice, C. O., and Kaufman, Y. J.: An enhanced contextual fire detection algorithm for MODIS, Remote Sens. Environ., 87, 273-282, 2003.

Giglio, L.: MODIS Collection 5 Active Fire Product User's Guide Version 2.4, Science Systems and Applications, Inc. University of Maryland, Department of Geography, 1-60, 2010.

Gillett, N. P., Weaver, A. J., Zwiers, F. W., and Flannigan, M. D.: Detecting the effect of climate change on Canadian forest fires, Geophys. Res. Lett., 31, L18211, doi:10.1029/2004GL020876, 2004.

Goetz, S. J., Mack, M. C., Gurney, K. R., Randerson, J. T., and Houghton, R. A.: Ecosystem responses to recent climate 
change and fire disturbance at northern high latitudes: observations and model results contrasting northern Eurasia and North America, Environ. Res. Lett., 2, 045031, doi:10.1088/17489326/2/4/045031, 2007.

Harden, J. W., Trumbore, S. E., Stocks, B. J., Hirch, A., Gower, S. T., O'Neill, K. P., and Kasischke, E. S.: The role of fire in the boreal carbon budget, Glob. Change Biol., 6, 174-184, 2000.

Harden, J. W., Manies, K. L., Turetsky, M. R., and Neff, J. C.: Effects of wildfire and permafrost on soil organic matter and soil climate in interior Alaska, Glob. Change Biol., 12, 2391-2403, 2006.

Hess, J. C., Scott, C. A., Hufford, G. L., and Fleming, M. D.: El Nino and its impact on fire weather conditions in Alaska, Int. J. Wildland Fire, 10, 1-13, 2001.

Hollingsworth, T. N., Johnstone, J. F., Bernhardt, E. L., and Chapin, F. S.: Fire severity filters regeneration traits to shape community assembly in Alaska's boreal forest, PLoS One, 8, e56033, doi:10.1371/journal.pone.0056033, 2013.

Hoy, E. E., French, N. H. F., Turetsky, M. R., Trigg, S. N., and Kasischke, E. S.: Evaluating the potential of Landsat TM/ETM+ imagery for assessing fire severity in Alaskan black spruce forests, Int. J. Wildl. Fire, 17, 500-514, 2008.

Johnstone, J. F. and Kasischke, E. S.: Stand-level effects of soil burn severity on postfire regeneration in a recently burned black spruce forest, Can. J. Forest Res., 35, 2151-2163, 2005.

Johnstone, J. F., Chapin, F. S., Hollingsworth, T. N., Mack, M. C., Romanovsky, V., and Turetsky, M.: Fire, climate change, and forest resilience in interior Alaska, dynamics of change in Alaska's boreal forests: resilience and vulnerability in response to climate warming, Can. J. Forest Res., 40, 1302-1312, 2010.

Johnstone, J. F., Rupp, T. S., Olson, M., and Verbyla, D.: Modeling impacts of fire severity on successional trajectories and future fire behavior in Alaskan boreal forests, Landscape Ecol., 26, 487$500,2011$.

Jorgenson, M. T., Romanovsky, V., Harden, J., Shur, Y., O'Donnell, J., Schuur, E. A. G., Kanevskiy, M., and Marchenko. S.: Resilience and vulnerability of permafrost to climate change, Can. J. Forest Res., 40, 1219-1236, 2010.

Kalnay, E., Kanamitsu, M., Kistler, R., Collins, W., Deaven, D., Gandin, L., Iredell, M., Saha, S., White, G., Woollen, J., Zhu, Y., Chelliah, M., Ebisuzaki, W., Higgins, W., Janowiak, J., Mo, K. C., Ropelewski, C., Wang, J., Leetmaa, A., Reynolds, R., Jenne, R., and Joseph, D.: The NCEP/NCAR 40-year reanalysis project, B. Am. Meteorol. Soc., 77, 437-471, 1996.

Kasischke, E. S. and Hoy, E. E.: Controls on carbon consumption during Alaskan wildland fires, Glob. Change Biol., 18, 685-699, 2012.

Kasischke, E. S., O’Neill, K. P., French, N. H. F., and BourgeauChavez, L. L.: Controls on pattern of biomass burning in Alaskan boreal forests, in: Fire, Climate Change and Carbon Cycling in the North American Boreal Forest, edited by: Kasischke, E. S. and Stocks, B. J., Springer, New York, 173-196, 2000.

Kasischke, E. S. and Turetsky, M. R.: Recent changes in the fire regime across the North American boreal region - spatial and temporal patterns of burning across Canada and Alaska, Geophys. Res. Lett., 33, L09703, doi:10.1029/2006GL025677, 2006.

Kasischke, E. S., Turetsky, M. R., Ottmar, D. N., French, H. F., Hoy, E. E., and Kane, E. S.: Evaluation of the composite burn index for assessing fire severity in Alaskan black spruce forests, Int. J. Wildland Fire, 17, 515-526, 2008.

Kasischke, E. S., Verbyla, D. L., Rupp, T. S., McGuire, A. D., Murphy, Karen, A., Jandt, R., Barnes, J. L., Hoy, E. E., Duffy, P. A., Calef, M., and Turetsky, M. R.: Alaska's changing fire regime - implications for the vulnerability of its boreal forests, Can. J. Forest Res., 40, 1313-1324, 2010.

Lee, X., Goulden, M. L., Hollinger, D. Y., Barr, A., Black, T. A., Bohrer, G., Bracho, R., Drake, B., Goldstein, A., Gu, L., Katul, G., Kolb, T., Law, B. E., Margolis, H., Meyers, T., Monson, R., Munger, W., Oren, R., Paw, U., K. T., Richardson, A. D., Schmid, H. P., Staebler, R., Wofsy, S., and Zhao, L.: Observed increase in local cooling effect of deforestation at higher latitudes, Nature, 479, 384-387, 2011.

Liu, H., Randerson, J. T., Lindfors, J., and Chapin, F. S.: Changes in the surface energy budget after fire in boreal ecosystems of interior Alaska: an annual perspective, J. Geophys. Res.-Atmos., 110, D13101, doi:10.1029/2004JD005158, 2005.

Loboda, T.V., Csiszar, I.A.: Reconstruction of fire spread within wildland fire events in Northern Eurasia from the MODIS active fire product, Global and Planetary Change, 56 (3-4), 258-273, 2007.

Loboda, T. V. and Csiszar, I. A.: Reconstruction of fire spread within wildland fire events in Northern Eurasia from the MODIS active fire product, Global Planet. Change, 56, 258-273, 2007.

Lyons, E. A., Jin, Y., and Randerson, J. T.: Changes in surface albedo after fire in boreal forest ecosystems of Interior Alaska assessed using MODIS satellite observations, J. Geophys. Res., 113, G02012, doi:10.1029/2007JG000606, 2008.

Mann, D. H., Rupp, T. S., Olson, M. A., and Duffy, P. A.: Is Alaska's boreal forest now crossing a major ecological threshold?, Arct. Antarct. Alp. Res., 44, 319-331, 2012.

McGuire, A. D., Anderson, L. G., Christensen, T. R., Dallimore, S., Guo, L., Hayes, D. J., Heimann, M., Lorenson, T. D., Macdonald, R. W., and Roulet, N.: Sensitivity of the carbon cycle in the Arctic to climate change, Ecol. Monogr., 79, 523-555, 2009.

Mesinger, F., DiMego, G., Kalnay, E., Mitchell, K., Shafran, P. C., Ebisuzaki, W., Jovic, D., Woollen, J., Rogers, E., Berbery, E. H., Ek, M. B., Fan, Y., Grumbine, R., Higgins, W., Li, H., Lin, Y., Manikin, G., Parrish, D., and Shi, W.: North American regional reanalysis, B. Am. Meteorol. Soc., 87, 343-360, 2006.

Murphy, K. A., Reynolds, J. H., and Koltun, J. M.: Evaluating the ability of the differenced Normalized Burn Ratio (dNBR) to predict ecologically significant burn severity in Alaskan boreal forests, Int. J. Wildland Fire, 17, 490-499, 2008.

Myers-Smith, I. H., Harden, J. W., Wilmking, M., Fuller, C. C., McGuire, A. D., and Chapin III, F. S.: Wetland succession in a permafrost collapse: interactions between fire and thermokarst, Biogeosciences, 5, 1273-1286, doi:10.5194/bg-5-1273-2008, 2008.

Nalder, I. A. and Wein, R. W.: Long-term forest floor carbon dynamics after fire in upland boreal forests of western Canada, Global Biogeochem. Cy., 13, 951-968, 1999.

Nossov, D. R., Torre Jorgenson, M., Kielland, K., and Kanevskiy, M. Z.: Edaphic and microclimatic controls over permafrost response to fire in interior Alaska, Environ. Res. Lett., 8, 035013, doi:10.1088/1748-9326/8/3/035013, 2013. 
Nowacki, G., Spencer, P., Brock, T., Fleming, M., and Jorgenson, T.: Ecoregions of Alaska and neighboring territory, U. S. Geological Survey, Reston, Va, 2001.

O’Donnell, J. A., Jorgenson, M. T., Harden, J. W., McGuire, A. D., Kanevskiy, M. Z., and Wickland, K. P.: The effects of permafrost thaw on soil hydrologic, thermal, and carbon dynamics in an Alaskan Peatland, Ecosystems, 15, 213-229, 2011.

Pechony, O. and Shindell, D. T.: Fire parameterization on a global scale, J. Geophys. Res.-Atmos., 114, D16115, doi:10.1029/2009JD011927, 2009.

Peterson, D., Wang, J., Ichoku, C., and Remer, L. A.: Effects of lightning and other meteorological factors on fire activity in the North American boreal forest: implications for fire weather forecasting, Atmos. Chem. Phys., 10, 6873-6888, doi:10.5194/acp10-6873-2010, 2010.

Reap, R. M.: Climatological characteristics and objective prediction of thunderstorms in Alaska, Weather Forecast., 6, 309-319, 1991.

Randerson, J. T., Liu, H., Flanner, M. G., Chambers, S. D., Jin, Y., Hess, P. G., Pfister, G., Mack, M. C., Treseder, K. K., Welp, L. R., Chapin, F. S., Harden, J. W., Goulden, M. L., Lyons, E., Neff, J. C., Schuur, E. A. G., and Zender, C. S.: The impact of boreal forest fire on climate warming, Science, 314, 1130-1132, 2006

Rogers, B. M., Randerson, J. T., and Bonan, G. B.: Highlatitude cooling associated with landscape changes from North American boreal forest fires, Biogeosciences, 10, 699-718, doi:10.5194/bg-10-699-2013, 2013.

Rupp, T. S., Chen, X., Olson, M., and McGuire, A. D.: Sensitivity of simulated boreal fire dynamics to uncertainties in climate drivers, Earth Interact., 11, 1-21, 2007.

Schwendel, A., Fuller, I., and Death, R.: Assessing DEM interpolation methods for effective representation of upland stream morphology for rapid appraisal of bed stability, River Res. Appl., 28, 567-584, 2012.

Silvestrini, R. A., Soares, B. S., Nepstad, D., Coe, M., Rodrigues, H., and Assuncao, R.: Simulating fire regimes in the Amazon in response to climate change and deforestation, Ecol. Appl., 21, 1573-1590, 2011.
Skinner, W. R., Stocks, B. J., Martell, D. L., Bonsal, B., and Shabbar, A.: The association between circulation anomalies in the mid-troposphere and area burned by wildland fire in Canada, Theor. Appl. Climatol., 63, 89-105, 1999.

Thorsteinsson, T., Magnusson, B., and Gudjonsson, G.: Large wildfire in Iceland in 2006: size and intensity estimates from satellite data, Int. J. Remote Sens., 32, 17-29, 2011.

Turetsky, M. R., Kane, E. S., Harden, J. W., Ottmar, R. D., Manies, K. L., Hoy, E., and Kasischke, E. S.: Recent acceleration of biomass burning and carbon losses in Alaskan forests and peatlands, Nat. Geosci., 4, 27-31, 2011.

Vaisala Oyj: Vaisala's NLDN US National Lightning Detection Network, Brochure, available at: http://www.vaisala.com/ Vaisala\%20Documents/Brochures\%20and\%20Datasheets/ NLDN-brochure-B210412EN-F-low.pdf (last access: 28 October 2013), 2011.

Van Wagner, C. E.: Development and structure of the Canadian Forest Fire Weather Index System, Canadian Forest Service Forestry Technical Report, 35, 1987.

Veraverbeke, S., Sedano, F., Hook, S. J., Randerson, J. T., Jin, Y., and Rogers, B.: Mapping the daily progression of large wildland fires using MODIS active fire data, Int. J. Wildl. Fire, doi:10.1071/WF13015, 2014.

Verbyla, D. and Lord, R.: Estimating post-fire organic soil depth in the Alaskan boreal forest using the normalized burn ratio, Int. J Remote Sens., 29, 3845-3853, 2008.

Verbyla, D. L., Kasischke, E. S., and Hoy, E. E.: Seasonal and topographic effects on estimating fire severity from Landsat TM/ETM+ data, Int. J. Wildland Fire, 17, 527-534, 2008.

Watson, D. and Philip, G.: A refinement of inverse distance weighted interpolation, Geoprocessing, 2, 315-327, 1985.

Wolfe, R. E., Roy, D. P., and Vermote, E.: MODIS land data storage,gridding and compositing methodology: Level 2 Grid, IEEE Trans. Geosci. Remote Sens., 36, 1324-1338, 1998.

Zimmermann, R., Schulze, E. D., Wirth, C., Schulze, E. E., McDonald, K. C., Vygodskaya, N. N., and Ziegler, W.: Canopy transpiration in a chronosequence of Central Siberian pine forests, Glob. Change Biol., 6, 25-37, 2000. 